\title{
QUALITY SELECTION AND GENETIC DIVERSITY OF TUNISIAN DURUM WHEAT VARIETIES USING SSR MARKERS
}

\author{
SELEÇÃO DE QUALIDADE E DIVERSIDADE GENÉTICA DE VARIEDADES DE \\ TRIGO DURO DA TUNÍSIA USANDO MARCADORES SSR
}

\author{
Elyes BABAY ${ }^{1}$; Sameh Rahmani MNASRI ${ }^{1 *}$; Rim MZID²; ${ }^{2}$ 'barek ben NACEUR $^{1}$; \\ Mohsen HANANA ${ }^{2}$
}

1. National Gene Bank, Boulevard du Leader Yasser Arafat, Z.I. la Charguia 1080 Tunis, Tunisia. mnasrisameh@yahoo.fr 2. Laboratoire des Plantes extrémophiles (LPE). Centre de Biotechnologie de Borj Cédria (CBBC). BP 901, Hammam-lif 2050, Tunisie.

\begin{abstract}
Our study focuses on the molecular analysis of the genetic diversity within 15 Tunisian durum wheat varieties and the assessment of the efficiency of some available markers to select valuable genotypes for technological proprieties of semolina (i.e. parameters related to SDS-sedimentation, mixing time and breakdown resistance of mixograph, grain protein content and yellow colour). While several markers were validated, others were not informative within the genotypes used. A high level of polymorphic information content (PIC) was detected, with an average of 5.2 polymorph alleles per locus and 0.6 average. Old varieties have high protein content however; modern varieties display strong gluten strength. Our results thus open the opportunity to choose valuable parents on the base of pedigrees, technological properties and genetic distances; and lead us to select efficient markers for the Regional Indigenous Land Strategy (Rils) selection strategy.
\end{abstract}

KEYWORDS: Durum wheat. Genetic diversity. SDS-sedimentation. Mixograph. Protein content. Yellow index.

\section{INTRODUCTION}

Durum wheat (Triticum turgidum L.ssp. durum (Desf.)) is cultivated on around 17 million hectares worldwide. It is a major crop in the Mediterranean basin, which is the largest producing area worldwide, the most significant import market and the largest consumer of durum wheat products (NAZCO et al. 2012). Durum wheat, in contrast to the common wheat (Triticum aestivum $\mathrm{L}$.), which is used to make bread and oriental style noodles, is the hardest wheat and durum milling produces a coarse particle called semolina, ideal for pasta and couscous production (SISSON 2008). Durum wheat with a grain protein content (GPC) and gluten strength, is known to be associated with firmness, assures good texture, non-stickiness and integrity of pasta after cooking (D'EGIDIO et al. 1990; ELIAS et al. 2005). Yellow pigment content (YPC), mainly resulting from xanthophyll lutein is the most important determinant of the bright yellow colour in semolina (HENTSCHEL et al. 2002). However, the final colour of pasta is also influenced by the enzymatic degradation of carotenoids by lipoxygenases (CARRERA et al. 2007).

Gluten strength is mainly affected by quality and quantity of gluten protein (BABAY et al. 2015). A combination of SDS-sedimentation, mixograph score and wheat protein predicted $71 \%$ of the variation in pasta firmness (DICK; QUICK 1983;
DICK; YOUNGS 1988). Mixograph and sedimentation volume (SV) were found to be good predictors of cooked pasta (KOVACS et al. 1995). Due to their reliability, they are used in durum wheat improvement programs to evaluate the gluten strength of breeding lines (DICK; YOUNGS 1988). Colorimetric determinations of semolina or flour are often used by breeders as tools to select materials with high yellow colour (RONCALLO et al. 2012). It is well known that about $70 \%$ of the variation of different dough-quality parameters can be explained by the variation in the storage-protein composition of the grain. Differences in dough properties and baking quality are largely determined by the superimposed effects of protein content, glutenin-togliadin ratio, the allelic compositions of the high (HMW-GS) and low (LMW-GS) molecular glutenin subunits, and the relative amounts of the different glutenin subunits (BABAY et al. 2015; PATIL et al. 2006; Vazquez et al. 1996).

The Glu-B3 locus (chromosome 1B) contributes significantly to gluten strength, whereas Glu-1 loci are poor indicators of gluten strength. The positive influence of Glu-A3, Glu-B2 and Gli$B 1$ (chromosomes $1 \mathrm{~A} / 1 \mathrm{~B}$ ) on gluten strength in the presence of $G l u-B 3$ has also been observed (MARTINEZ et al. 2004 AND 2005). The yellow pigment content (YPC) in grains and the yellow colour of milling products are considered as complex heritable traits controlled by several 
genomic regions (CLARKE et al. 2006). The genetic architecture of these traits has been investigated through a quantitative trait locus (QTL) analysis in durum and bread wheat, using different mapping populations and a large number of genomic regions was reported such as chromosomes 4A (SOMERS et al. 2004), 1B, 6A and 7A (ZHANG et al. 2008). It has been suggested that the identification of genes influencing dough quality, other than those controlling the gluten fraction, might be a useful way to collect more information about genes influencing dough quality (LAW et al. 2005). GUPTA et al. (2002) have identified QTLs for dough strength on chromosome 1B. From these and other similar studies, markers that are linked to the QTL can be identified and used in breeding programs. Molecular markers have been used to study genetic diversity, identification and mapping of genes and QTLs for numerous important traits in wheat, including pasta/semolina quality characteristics. Many markers are not validated across wheat genotypes or are not polymorphic within wheat breeding populations.

In the present study, we examined the genetic diversity of some durum wheat genotypes, grown in North Africa (since 1893) by means of 28 Simple sequence repeats (SSRs) markers. Marker primers were associated with the various indicators of technological quality parameters investigated in Durum wheat (SDS-sedimentation, Mixogram, GPC, yellow index) and were obtained from published literature. We evaluated the technological quality of genotypes grown in field conditions during two seasons and examined the efficiency of the available markers for quality parameters, in order to use them in future programs

\section{MATERIAL AND METHODS}

\section{Seed material and field experiments}

Fifteen varieties of durum wheat (Triticum turgidum L. subsp. Durum Desf.) cultivated in farmlands in Tunisia since 1893 were used in this study (Table 1). All genotypes were sown in a randomized complete-block design with two replicates per genotype, during two seasons 20092010 and 2010-2011, and the plants were grown under rainfed conditions in the experimental station of the Center of Biotechnology of Borj-Cédria (Tunisia).

Table 1. Pedigree, origin and year of selection of genotypes.

\begin{tabular}{|c|c|c|}
\hline Genotypes & Pedigree & $\begin{array}{c}\text { Origin/year of } \\
\text { selection/introduction in } \\
\text { Tunisia }\end{array}$ \\
\hline Baîdha & Old variety & Tunisia \\
\hline Biskri Pubescent & Old variety & Algeria, 1909 \\
\hline Chili & Old variety & French, 1932 \\
\hline Derbassi Ap2 & Old variety & Tunisia, 1909 \\
\hline Grécale & S2/WB881//Plinio/F22 & Italy, 2004 \\
\hline Inrat 69 & Mahmoudi/Kyperounda & INRAT. Tunisia, 1969 \\
\hline Iride & Altar 84/Ionio & Italy, 2004 \\
\hline Karim80 & Jori"S"/Anhinga“"S"//Flamingo“S” & CIMMYT-Mexico, 1973 \\
\hline Khiar & Chen'S'/Altar 84 & CIMMYT-Mexico, 1987 \\
\hline Mahmoudi & Old variety & Tunisia, 1893 \\
\hline Nasr99 & GoVZ512/Cit//Ruff/Fg/3/Pin/Gre//Trob & ICARDA-Syria, 1985 \\
\hline Om Rabi5 & Jori C69/ Hau & ICARDA-Syria, 1996 \\
\hline Richi & Old variety (has Triticum polonicum species parent) & $1908 / 1909$ \\
\hline Saragolla & Iride/LineaPSB 0114 & Italy, 2004 \\
\hline Swabaa Algia & Old variety & North of Tunisia, 1909 \\
\hline
\end{tabular}

\section{DNA isolation and SSR analysis}

Genomic DNA was extracted from young leaves of 3-week-old plants grown from representative seeds of any genotype using the "ZR Plant/Seed DNA Kit ${ }^{\mathrm{TM}}$ " (ZYMO RESEARCH) according to the manufacturer's instructions. DNA concentration was measured using a Biophotometer (Eppendorf) and adjusted to a final concentration of $25 \mathrm{ng} / \mu \mathrm{l}$. The twenty-eight microsatellite primers used are associated to Quantitative Traits Loci (QTL) that are linked to some technological quality traits (strength and elasticity of gluten, grain protein content, yellow color index) designated in previous studies (Table 2). PCR reactions were carried out in a $25 \mu \mathrm{l}$ reaction volume containing $1 \mathrm{U}$ of Taq polymerase, 50-100 ng of template DNA, $0.25 \mu \mathrm{M}$ of each primer, $0.2 \mathrm{mM}$ of each dNTP, $2 \mathrm{mM}$ of $\mathrm{MgCl}_{2}$ and 1X PCR reaction buffer. Amplifications 
were performed in a DNA thermocycler (Applied Biosystems. Veriti 96 well, thermal cycler) programmed for one cycle of $95^{\circ} \mathrm{C}$ for $3 \mathrm{~min}$ and 35 consecutive cycles of $\left[1 \mathrm{~min}\right.$ denaturing at $94^{\circ} \mathrm{C}, 1$ min annealing temperature at $\mathrm{X}^{\circ} \mathrm{C}$ (specific to each primer) and $2 \mathrm{~min}$ extension at $72^{\circ} \mathrm{C}$ ] followed by a final elongation of $10 \mathrm{~min}$ at $72^{\circ} \mathrm{C}$. Amplified PCR products were separated by electrophoresis using a $3 \%$ agarose 1x Tris- Acetate-EDTA buffer ( $\mathrm{pH} 8.3$ ) (TAE) gel, stained with $0.5 \mathrm{mg} / \mathrm{ml}$ ethidium bromide, and visualized under UV light and photographed by a Gel Documentation System (GDS). A 100 bp DNA ladder (Promega) was used as a molecular marker of standard sizes.

\section{Evaluation of qualitative traits}

Gluten strength was estimated by the SDSsedimentation test (SDSS) with some minor modifications (CARRILLO et al. 1991; DICK and QUICK 1983). Protein content (Prot) at $14 \%$ moisture was estimated by a near-infrared reflectance analyser (the Inframatic 8120 Analysis ENMP $^{\circledR}$ ). To assess mixing properties, whole-wheat meal was sieved to a particle size of $125-315 \mathrm{~mm}$ and used in the 10-g mixograph (FINNEY and SHOGREN, 1972) with modification for constant water absorption of $6.5 \mathrm{ml}$. The mixograph parameters estimated were: mixing development time (MT), maximum peak height (MH), height at 3 min after the peak of the curve (H3), and the difference in percentage between $\mathrm{MH}$ and $\mathrm{H} 3$ (resistance to breakdown, BDR). Yellow colour index was estimated on whole grain flour by means of a reflectance colorimeter (CR-300, KonicaMinolta) equipped with a filter tri-stimulate system, the values of semolina colour index measured are $b^{*}$ (yellow colour), $\mathrm{L}^{*}$ (brightness) and $\mathrm{a}^{*}$ (red colour).

\section{Statistical analysis \\ Cluster analysis}

Amplified fragments were classified as present (represented by 1) or absent (represented by 0 ) for SSR analyses. A data matrix was designed for the analysis. A pair-wise similarity matrix was generated with the software NTSYSpc-2.02 $\mathrm{j}$ (NTSYS-Numerical Taxonomy and Multivariate Analysis; Rohlf 1998) using a simple matching coefficient (Sokal et al. 1958). A dendrogram was then drawn based on the similarity matrix data using the UPGMA (Unweighted Pair-Group Method using Arithmetic Averages) cluster analysis of NTSYSpc$2.02 \mathrm{j}$ (Figure 1).

Degree of polymorphism

The data matrix was used to compute the diversity for each SSR marker. This is equivalent to the polymorphism information content (PIC) at each SSR as described in the following equation by ANDERSON (1992): $\mathrm{PIC}=1-\sum_{\mathrm{j}=1}^{\mathrm{n}} \mathrm{P}_{\mathrm{ij}}^{2}$ Where $\mathrm{P}_{\mathrm{ij}}$ is the allele frequency of the $\mathrm{j}^{\text {th }}$ allele for the $\mathrm{i}^{\text {th }}$ marker summed over and the summation covers $n$ patterns.

PIC is also an estimation of the discriminatory power of an SSR marker locus. The frequencies of null alleles were not included in the calculation of PIC values.

\section{Correlation between primers polymorphism and qualities}

Analysis of variance and Duncan procedures between primer variation and quality parameters for each genotype were conducted on the average values of test results using the SAS statistical software (SAS institute, Cary, NC).

\section{RESULTS}

\section{Wheat microsatellites and genetic diversity}

In this study we used twenty-eight SSRs from which twenty-three gave a polymorphs locus, although, thirty-three loci were identified. A summary of the estimated number of alleles and PIC values for all primers is provided in Table 2. A total of 120 alleles was identified in all varieties. The number of alleles per primer varied from 2 (for $w m c 49$ and gwm369) to 12 (for $C f a 2129$ ) with an average of 5.2 polymorphs alleles per locus (Table 2 ). The highest and lowest PIC value were 0.929 (Cfa2129) and 0.13 (gwm369), respectively, with an average value of $\mathrm{PIC}=0.6$

\section{Cluster analysis}

The genetic similarity values between genotypes used to produce a dendrogram ranged from 63\% (between 'Swabâa Algia' and 'Grécale'), to $96 \%$ (between 'Mahmoudi' and 'Chili'). At genetic similarity of about $74 \%$, the dendrogram data discriminated the variety 'Derbassi' from the rest of the genotypes analysed, which were clustered in three major groups of similar genotypes (Figure 1). The first group contains four old varieties (Swabâa Algia, Richi, Biskri and Baïdha). The second group is composed of two subgroups; the first subgroup is formed by three old genotypes (Inrat69, Mahmoudi and Chili) and the second subgroup contains two cultivars improved by ICARDA (Om Rabii and Nasr). The third group, containing five modern varieties, is divided into two subgroups: in the first subgroup are two cultivars 
improved by CIMMYT (karim and Khiar) and in the second subgroup, three Italian cultivars (Grécale, Iride and Saragolla) Figure 1).

Table 2. Information and relative results of primers

\begin{tabular}{|c|c|c|c|c|c|}
\hline Primers & PIC & $\begin{array}{c}\mathbf{N}^{\circ} \text { allele } \\
\text { (rare) }\end{array}$ & Traits & Chr & Ref \\
\hline WMC49 & 0.48 & $3(1)$ & GPC / GS & 1B & (1) \\
\hline WMC329 & 050 & $2(0)$ & GPC / GS & 1B & (2) \\
\hline WMC51 & 0.42 & $3(1)$ & GPC / GS & 1B & (2) \\
\hline WMC550 & - & - & GPC / GS & $1 \mathrm{~A}$ & (2) \\
\hline WMC798 & 0.56 & $4(1)$ & GPC / GS & 1B & (2) \\
\hline WMC619 & 0.78 & $6(1)$ & GPC / GS & 1B & (2) \\
\hline GWM374 & - & - & GPC / GS & $2 \mathrm{~B} / 3 \mathrm{~A}$ & (2) \\
\hline GWM550 & - & - & GPC / GS & $1 \mathrm{~B} / 7 \mathrm{~A}$ & (2) \\
\hline GWM608 & - & - & GPC / GS & $6 \mathrm{~B}$ & (2) \\
\hline GWM5 & 0.76 & $7(4)$ & GPC/GS & $3 \mathrm{~A}$ & (3) \\
\hline GWM68 & 0.83 & $7(2)$ & GS & $3 \mathrm{~A}$ & (3) \\
\hline GWM369 & 0.13 & $2(1)$ & GPC & $3 \mathrm{~A}$ & (3) \\
\hline BARC355 & 0.76 & 7(4) & GS & $5 \mathrm{~A}$ & (4) \\
\hline PSP3030 & 0.67 & $4(1)$ & GPC & 4B & (4) \\
\hline Cfd079b & 0.83 & $7(2)$ & GPC & $3 \mathrm{~A} / 3 \mathrm{~B}$ & (3) \\
\hline WMC621 & 0.64 & $3(0)$ & GS & $6 \mathrm{~A} / 6 \mathrm{~B}$ & (5) \\
\hline CFA2129 & 0.91 & $12(9)$ & GS & $1 \mathrm{~A}$ & (5) \\
\hline WMC110 & 0.74 & $8(6)$ & GS & $5 \mathrm{~A}$ & (5) \\
\hline BARC101 & 0.65 & $4(1)$ & GPC & $2 \mathrm{~B} / 6 \mathrm{~B}$ & (5) \\
\hline BARC83 & 0.23 & $2(0)$ & GPC & $1 \mathrm{~A}$ & (5) \\
\hline BARC231 & 0.24 & $3(2)$ & GPC & $7 \mathrm{~A}$ & (4) \\
\hline GWM573 & 0.42 & $3(1)$ & GPC & $7 \mathrm{~A} / 7 \mathrm{~B}$ & (4) \\
\hline GWM46 & 0.49 & $5(2)$ & GPC & $7 \mathrm{~B}$ & (4) \\
\hline BARC240 & 0.65 & $4(1)$ & YC & 1B & (5) \\
\hline GWM146 & - & - & $\mathrm{YC}$ & $7 \mathrm{~B}$ & (5) \\
\hline WMC722 & 0.87 & $9(4)$ & YC & $4 \mathrm{~A}$ & (2) \\
\hline WMC553 & 0.34 & $3(1)$ & $\mathrm{YC}$ & $6 \mathrm{~A}$ & (5) \\
\hline WMC116 & 0.88 & $12(11)$ & $\mathrm{YC}$ & $7 \mathrm{~A}$ & (5) \\
\hline Cfd079b & 0.83 & $7(2)$ & GPC & $3 \mathrm{~A} / 3 \mathrm{~B}$ & (3) \\
\hline WMC621 & 0.64 & $3(0)$ & GS & $6 \mathrm{~A} / 6 \mathrm{~B}$ & (5) \\
\hline CFA2129 & 0.91 & $12(9)$ & GS & $1 \mathrm{~A}$ & (5) \\
\hline WMC110 & 0.74 & $8(6)$ & GS & $5 \mathrm{~A}$ & (5) \\
\hline BARC101 & 0.65 & $4(1)$ & GPC & $2 \mathrm{~B} / 6 \mathrm{~B}$ & (5) \\
\hline BARC83 & 0.23 & $2(0)$ & GPC & $1 \mathrm{~A}$ & (5) \\
\hline BARC231 & 0.24 & $3(2)$ & GPC & $7 \mathrm{~A}$ & (4) \\
\hline GWM573 & 0.42 & $3(1)$ & GPC & $7 \mathrm{~A} / 7 \mathrm{~B}$ & (4) \\
\hline GWM46 & 0.49 & $5(2)$ & GPC & $7 \mathrm{~B}$ & (4) \\
\hline BARC240 & 0.65 & $4(1)$ & YC & 1B & (5) \\
\hline GWM146 & - & - & $\mathrm{YC}$ & $7 \mathrm{~B}$ & (5) \\
\hline WMC722 & 0.87 & $9(4)$ & YC & $4 \mathrm{~A}$ & (2) \\
\hline WMC553 & 0.34 & $3(1)$ & $\mathrm{YC}$ & $6 \mathrm{~A}$ & (5) \\
\hline WMC116 & 0.88 & $12(11)$ & $\mathrm{YC}$ & $7 \mathrm{~A}$ & (5) \\
\hline
\end{tabular}

Ref: reference, Chr: chromosome, $\mathrm{N}^{\circ}$ : number; (YC): Yellow Color; (GPC): grain protein content; (GS): gluten strength; (1): Gupta et al. 2002 and Knox et al. 2004. (2): Somers et al. 2004 ; (3): Brevet (WO/2004/083368). (4) Patil R.M. et al. 2009. (5) Zhang W. et al. 2008 


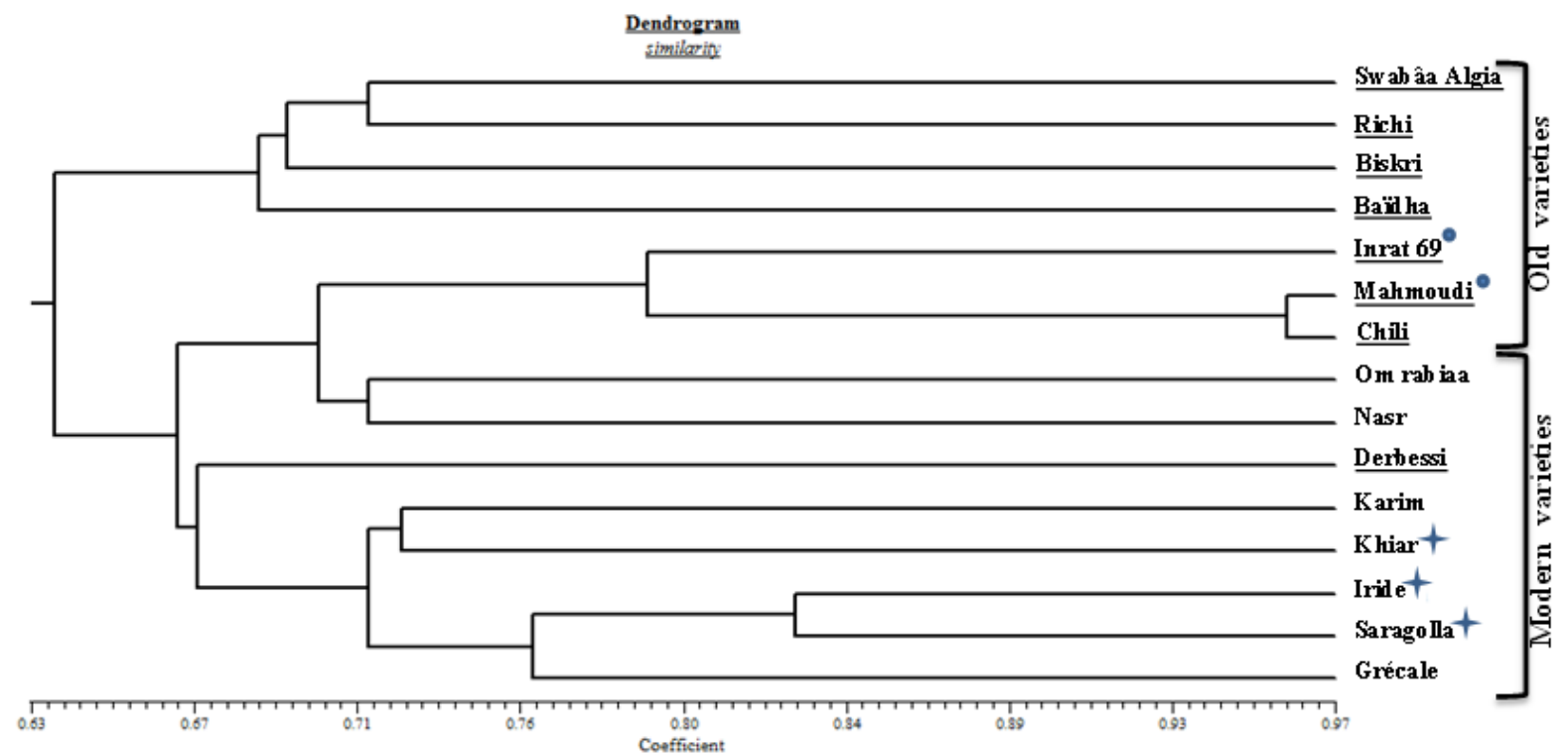

Figure 1. Dendrogram of genetic similarities based on UPGMA method.

- and +indicate presence of parentage links between genotypes. Old varieties are underlines.

\section{Evaluation of quality parameters}

The analysis of quality in this study demonstrates a large variability for each parameter in all genotypes. The protein content at $14 \%$ moisture varied from $10.6 \%$ for 'Khiar' to $12.8 \%$ for 'Biskri' and 'Chili' with an average of $11.3 \%$. SDS-sedimentation values varied from $16 \mathrm{~mm}$ for 'Swabâa Algia' to $71 \mathrm{~mm}$ for 'Saragolla' with an average of $50.22 \mathrm{~mm}$. For mixogram parameters, mixing time varied from $55.1 \mathrm{~s}$ for 'Swabâa Algia' to $226.9 \mathrm{~s}$ for 'Nasr' with an average of $163.7 \mathrm{~s}$. For BDR, lower values are better; BDR varied from 28.2 for 'Swabâa Algia' to 11.2 for 'Saragolla' with an average of 15.5. The semolina colour parameter $b^{*}$ (indices of yellow colour) varied from 13.9 for 'Karim' to 20.9 for 'Grécale' with an average of 18.5. Overall, modern varieties display better mixograph (MT and BDR) and SDS-sedimentation parameters than old varieties. However, landraces are distinguished by the high level of protein content and colour yellow index (Table 3 ).

\section{Markers efficiency in the selection of quality}

The analysis of variance and Duncan's multiple range tests are used to study the efficiency of some SSR molecular markers described by KNOX et al. (2004); SOMERS et al. (2004), BREVET (WO/2004/083368); ZHANG et al. (2008) and PATIL et al. (2009) to assist in the selection of genotypes according to some technological quality parameters of wheat. No significant correlation was found between protein content and primers studied (Table 4). The_markers that are correlate with SDS-sedimentation and mixograph parameters (mixing time and breakdown resistance) are present in detail in Table 4. High correlation between markers and character detected in GWM68 and WMC619. This two markers correlate with three parameters (MT, BDR and SDSS) at the same time.

We ranked the different sizes of bands (bp) of different alleles provided by the two markers from good to poor gluten strength:

gwm68:(143/180bp $) \geq(143 / 185 \mathrm{bp}) \geq(150 / 20$

$0 \mathrm{bp}) \geq(147 / 190 \mathrm{bp}) \geq(150 / 190 \mathrm{bp}) \geq(147 / 180 \mathrm{bp}) \geq(150 /$ 185bp)

wmc619:(224/89bp $) \geq(224 / 93 / 89 b p) \geq(204 / 9$ $3 / 89 b p) \geq(224 / 93 b p) \geq(170 / 89 b) \geq(204 / 89 b p)$

No significant correlation was detected between colour index and primers tested. Although, the colorimetric values $\left(\mathrm{a}, \mathrm{b}^{*}, \mathrm{~L}\right)$ have shown a significant correlation among them. The brightness index $(\mathrm{L})$ has shown negative correlations with $\left(\mathrm{b}^{*}\right)$ and (a) respectively equal to $-0,75$ et $-0,66$ and a positive correlation between (a) and $\left(b^{*}\right)$ equivalent at 0,33 . 
Table 3. Results of quality tests (means and ranges) of 15 Tunisian durum wheat Landraces and Cultivars.

\begin{tabular}{|c|c|c|c|c|c|c|c|c|c|c|c|c|c|c|}
\hline \multirow[b]{3}{*}{ Old Var } & \multirow{2}{*}{\multicolumn{2}{|c|}{$\begin{array}{c}\text { Protein } \\
(14 \% \text { moisture })(\%)\end{array}$}} & \multirow{2}{*}{\multicolumn{2}{|c|}{$\begin{array}{c}\text { SDS-sedimentation } \\
(\mathrm{mm})\end{array}$}} & \multicolumn{4}{|c|}{ Mixogram } & \multicolumn{6}{|c|}{ Semolina Colour } \\
\hline & & & & & \multicolumn{2}{|c|}{ MT(s) } & \multicolumn{2}{|c|}{ BDR } & \multicolumn{2}{|c|}{$\mathbf{a}^{*}$} & \multicolumn{2}{|c|}{$\mathbf{b}^{*}$} & \multicolumn{2}{|c|}{$\mathbf{L}^{*}$} \\
\hline & means & range & means & range & means & range & means & range & means & range & means & range & means & range \\
\hline Baydha & 12.6 & $11.8-14.2$ & 43.0 & $40.5-45.5$ & 125.2 & $105.7-150.0$ & 18.2 & $15.2-20.0$ & 2.5 & $2.3-2.7$ & 18.0 & $17.8-18.2$ & 81.4 & $80.7-82.7$ \\
\hline Biskri & 12.8 & $11.8-13.9$ & 30.0 & $29.0-32.0$ & 81.0 & $79.2-82.5$ & 21.3 & $19.4-24.6$ & 2.6 & $2.4-2.7$ & 19.8 & $19.4-20.1$ & 80.4 & 80.0-80.8 \\
\hline Chili & 12.8 & $11.2-13.9$ & 29.0 & $21.5-36.5$ & 113.7 & $85.8-146.2$ & 14.3 & $11.6-17.2$ & 2.7 & $2.6-2.8$ & 19.2 & $18.5-19.5$ & 79.8 & $79.5-80.3$ \\
\hline Derbassi & 12.1 & $11.1-14.8$ & 36.6 & $25.0-44.0$ & 117.0 & $110.0-125.4$ & 15.7 & $12.5-21.2$ & 1.5 & $1.4-1.6$ & 19.3 & 19.0-19.9 & 83.4 & $83.3-83.5$ \\
\hline Inrat 69 & 11.8 & $10.8-12.4$ & 30.3 & $24.0-34.0$ & 103.6 & $61.2-129.1$ & 19.4 & $14.8-23.7$ & 2.4 & $2.2-2.5$ & 19.7 & $19.1-20.1$ & 80.2 & 79.6-80.1 \\
\hline Mahmoudi & 11.7 & $10.9-12.5$ & 33 & $31.5-34.5$ & 143.6 & $128.7-155.1$ & 17.4 & $16.4-19.4$ & 2.2 & $2.0-2.4$ & 18.3 & $18.0-18.5$ & 82.2 & $81.7-82.6$ \\
\hline Richi & 12.7 & $12.3-13.1$ & 22.8 & $20.0-26.5$ & 81.2 & $62.7-92.4$ & 21.2 & $17.2-22.5$ & 2.6 & $2.4-2.9$ & 19.4 & $19.2-19.7$ & 79.5 & 78.4-80.9 \\
\hline $\begin{array}{c}\text { SwbâaAlgia } \\
\text { Average }\end{array}$ & $\begin{array}{l}12.4 \\
12.4\end{array}$ & $\begin{array}{l}10.8-14.1 \\
10.8-14.8\end{array}$ & $\begin{array}{l}16.0 \\
30.0\end{array}$ & $\begin{array}{l}15.5-16.5 \\
15.5-45.5\end{array}$ & $\begin{array}{c}55.1 \\
102.5\end{array}$ & $\begin{array}{c}40.1-70.2 \\
40.1-155.1\end{array}$ & $\begin{array}{l}28.2 \\
19.5\end{array}$ & $\begin{array}{c}25-30.7 \\
12.5-30.7\end{array}$ & $\begin{array}{l}2.5 \\
2.4\end{array}$ & $\begin{array}{l}2.2-2.7 \\
1.4-2.9\end{array}$ & $\begin{array}{l}19.7 \\
19.2\end{array}$ & $\begin{array}{l}19.3-20.2 \\
17.8-20.2\end{array}$ & $\begin{array}{l}80.5 \\
80.9\end{array}$ & $\begin{array}{l}79.4-81.2 \\
78.4-83.5\end{array}$ \\
\hline \multicolumn{15}{|l|}{ Modern Var } \\
\hline Grécale & 11.6 & $11.1-11.9$ & 62.5 & $47.0-77.5$ & 155.4 & $135.0-165.0$ & 15.8 & $10.8-21.0$ & 1.3 & $1.1-1.4$ & 20.9 & $20.7-21.3$ & 81.4 & $81.0-81.8$ \\
\hline Iride & 11.3 & $10.4-12.0$ & 63.1 & $52.0-76.0$ & 222.3 & $160.5-283.8$ & 12.4 & $4.8-15.9$ & 1.7 & $1.3-1.9$ & 19.8 & 19.4-19.9 & 81.0 & $80.2-82.1$ \\
\hline Karim & 11.2 & $10.8-11.3$ & 22.0 & $20.5-27.5$ & 81.3 & $64.5-99.0$ & 18.5 & 16.6-19.6 & 1.0 & $0.9-1.2$ & 13.9 & $13.8-14.0$ & 85.9 & $85.4-86.3$ \\
\hline Khiar & 10.6 & $9.8-11.8$ & 53.8 & $41.5-64.5$ & 153.0 & $102.3-204.0$ & 12.6 & $7.5-16.4$ & 2.0 & $1.9-2.2$ & 18.2 & $17.9-18.5$ & 80.2 & $78.3-81.8$ \\
\hline Nasr & 11.1 & $10.7-11.5$ & 58.3 & $54.0-68.0$ & 226.9 & $199.1-255$ & 15.7 & $11.7-22.0$ & 2.3 & $2.0-2.6$ & 17.7 & $17.1-18.2$ & 81.0 & $79.7-82.7$ \\
\hline Om Rabii & 12.3 & $11.3-13.2$ & 20.9 & $18.5-25.0$ & 87.2 & $62.7-102.3$ & 22.2 & $18.2-25.0$ & 1.9 & $1.7-2.2$ & 20.6 & $19.3-21.7$ & 81.0 & $80.3-81.9$ \\
\hline Saragolla & 11.6 & $10.6-11.5$ & 71.0 & $60.0-82.0$ & 219.7 & $181.1-260.3$ & 11.2 & 4.9-17.5 & 1.9 & $1.8-2.1$ & 18.2 & 18.1-18.6 & 82.1 & $81.7-82.3$ \\
\hline Average & 11.3 & $9.8-13.2$ & 50.22 & $20.5-82.0$ & 163.7 & $62.7-283.8$ & 15.5 & $4.8-25.0$ & 1.7 & $0.9-2.6$ & 18.5 & $13.8-21.7$ & 81.8 & $78.3-86.3$ \\
\hline
\end{tabular}

Var: varieties; MT: Mixing times; BDR: Breakdown Resistance; $a^{*}$ : red colour; $b^{*}$ : yellow colour, L*: brightness 
Table 4. Signification of correlation between markers and technological parameters studied

\begin{tabular}{|c|c|c|c|c|c|c|c|c|c|c|}
\hline & $\begin{array}{l}\text { barc35 } \\
5\end{array}$ & $\begin{array}{l}\text { gwm4 } \\
6\end{array}$ & $\begin{array}{l}\text { psp303 } \\
0\end{array}$ & $\begin{array}{l}\text { gwm36 } \\
9\end{array}$ & $\begin{array}{l}\text { barc23 } \\
1\end{array}$ & gwm5 & $\begin{array}{l}\text { wmc4 } \\
9\end{array}$ & $\begin{array}{l}\text { wmc32 } \\
9\end{array}$ & $\begin{array}{l}\text { gwm57 } \\
3\end{array}$ & $\begin{array}{l}\text { wmc61 } \\
9\end{array}$ \\
\hline MT & $*$ & n.s. & $*$ & n.s. & n.s. & $* *$ & $*$ & $*$ & n.s. & $*$ \\
\hline BDR & $*$ & $*$ & $*$ & $*$ & $*$ & n.s. & $* *$ & n.s. & n.s. & $* *$ \\
\hline SDSS & n.s. & n.s. & n.s. & n.s. & n.s. & n.s. & n.s. & n.s. & n.s. & $* *$ \\
\hline $\begin{array}{l}\text { PRO } \\
\mathrm{T}\end{array}$ & n.s. & n.s. & n.s. & n.s. & n.s. & n.s. & n.s. & n.s. & n.s. & n.s. \\
\hline$a^{*}$ & n.s. & n.s. & n.s. & n.s. & n.s. & n.s. & n.s. & n.s. & n.s. & n.s. \\
\hline$b^{*}$ & n.s. & n.s. & n.s. & n.s. & n.s. & n.s. & n.s. & n.s. & n.s. & n.s. \\
\hline $\mathrm{L}^{*}$ & $\begin{array}{c}\text { n.s. } \\
\text { wmc79 } \\
8\end{array}$ & $\begin{array}{c}\text { n.s. } \\
\text { wmc5 } \\
1\end{array}$ & $\begin{array}{c}\text { n.s. } \\
\text { gwm68 }\end{array}$ & $\begin{array}{c}\text { n.s. } \\
\text { cfa2129 }\end{array}$ & $\begin{array}{c}\text { n.s. } \\
\text { wmc11 } \\
\mathbf{0}\end{array}$ & $\begin{array}{c}\text { n.s. } \\
\text { wmc62 } \\
1\end{array}$ & $\begin{array}{c}\text { n.s. } \\
\text { gag5 }\end{array}$ & $\begin{array}{l}\text { n.s. } \\
\text { cfd79 }\end{array}$ & $\begin{array}{c}\text { n.s. } \\
\text { barc10 } \\
1\end{array}$ & $\begin{array}{c}\text { n.s. } \\
\text { barc83 }\end{array}$ \\
\hline MT & n.s. & $*$ & $* *$ & $* *$ & $*$ & n.s. & n.s. & * & n.s. & n.s. \\
\hline $\begin{array}{l}\text { BDR } \\
\text { SDSS }\end{array}$ & $\begin{array}{l}\text { n.s. } \\
* *\end{array}$ & $\begin{array}{l}\text { n.s. } \\
\text { n.s. }\end{array}$ & $\begin{array}{l}* * \\
* *\end{array}$ & $\begin{array}{c}\text { n.s. } \\
*\end{array}$ & $\begin{array}{l}\text { n.s. } \\
\text { n.s. }\end{array}$ & $\begin{array}{l}\text { n.s. } \\
\text { n.s. }\end{array}$ & $\begin{array}{l}\text { n.s. } \\
\text { n.s. }\end{array}$ & $\begin{array}{c}\text { n.s. } \\
*\end{array}$ & $\begin{array}{l}\text { n.s. } \\
\text { n.s. }\end{array}$ & $\begin{array}{c}\text { n.s. } \\
*\end{array}$ \\
\hline $\begin{array}{l}\text { PRO } \\
\mathrm{T}\end{array}$ & n.s. & n.s. & n.s. & n.s. & n.s. & n.s. & n.s. & n.s. & n.s. & n.s. \\
\hline$a^{*}$ & n.s. & n.s. & n.s. & n.s. & n.s. & n.s. & n.s. & n.s. & n.s. & n.s. \\
\hline$b^{*}$ & n.s. & n.s. & n.s. & n.s. & n.s. & n.s. & n.s. & n.s. & n.s. & n.s. \\
\hline L* & n.s. & n.s. & n.s. & n.s. & n.s. & n.s. & n.s. & n.s. & n.s. & n.s. \\
\hline
\end{tabular}

n.s. $=$ no significant; *significant at $5 \%$, and $* *$ significant at $1 \%$

\section{DISCUSSION}

By displaying an average PIC value of 0.6, the markers confirm that the SSR markers used in this study were highly informative. Markers with PIC values of 0.5 or more are highly informative for genetic studies and are extremely useful in distinguishing the polymorphism rate of markers at specific loci (SUNDARAM et al. 2007). The microsatellite markers used have been able to differentiate most varieties based on old varieties (Tunisian landraces) or modern cultivars (improved) and based on parentage links. 'Khiar' and 'Iride' have 'Altar 84' as common parent. 'Iride' is a parent of 'Saragolla' and 'Mahmoudi' a parent of 'Inrat 69'. The modern cultivars are also sub-grouped on the basis of their origin (Figure 1, Table 1). Nasr and Om Rabiaa derived from crosses made in ICARDA-Syria (sub-groupe 1), Karim and khiar derived from crosses made in CIMMYT-Mexico (sub-groupe2) and Iride, Saragolla and Grécale are third from Italy (sub-groupe 3 ).

No correlation has been revealed between the grain protein content (GPC) and the polymorphism of the marker used. Breeding for an increase in GPC is difficult because the genetic variation for this character is small compared to variations caused by the environment; moreover, a negative correlation has frequently been foundbetween GPC and grain yield in segregating populations in all cereals (BABAY et al. 2015). Only the high grain protein content (Gpc-B1) gene transferred from Triticum turgidum ssp. Dicoccoides into durum wheat is a valuable resource to increase GPC (JOPPA et al. 1990; MESFIN et al. 1999; KHAN et al. 2000; BREVIS et al. 2010). It appears that many of the available markers may need to be further refined or examined for trait association and presence of polymorphism in breeding lines and populations. The results of gluten strength measured by the SDSsedimentation test for the allelic variant of 23 loci revealed that three markers influenced this parameter in a significant way at 1\% (WMC619, WMC798 and GWM68) and three molecular markers at 5\% (Table 4). For the mixing time parameter of the mixogram, we showed three loci whose influence was 1\% significance (CFA2129, GWM5 and GWM68) and eight primers of significance at 5\% (Table 4). For the breakdown resistance (BDR), we selected three markers at $1 \%$ significance (WMC49, WMC619 and GWM68) and five others primers significant at 5\% (Table 4).

The major determinants of wheat quality are Glu-1 and Glu-3 glutenin loci and environmental factors (LANGNER et al. 2017). . For more efficiency in breeding program, we can added the markers with $1 \%$ significance of each specific parameter (Table 4). We thus confirm the studies that found a correlation between SDSsedimentation, mixing time and breakdown resistance (BRITES and CARRILLO, 2001; MARTÍNEZ et al. 2005; EDWARDS et al. 2007). Our results show that GWM68 and WMC619 are good molecular markers of technological qualities 
of durum wheat. We can use them in Tunisian breeding programs associated with interesting subunits of gliadin and glutenin (e.g., Gli- $\gamma-45$ and $G l i-\gamma-42$ are respectively markers of good and poor gluten strength) (MARTÍNEZ et al. 2005: EDWARDS et al. 2007). On the other hand, the failure of some markers to select specific traits could be due to various reasons, including the absence of complementary genomic sequences with the primers used, breakdown of linkages between markers and genes, and differences and artefacts in PCR conditions (PANTHEE et al. 2012). Molecular markers associated with genes or QTLs underlying many complex quality traits in wheat have been identified. Theoretically, the marker information should be useful to improve such traits via markerassisted breeding. However, not all markers reported in the literature are readily applicable in wheat breeding programs. Often additional efforts are needed to refine the markers or to identify and develop new polymorphic markers with greater utility and reproducibility in specific breeding populations (PANTHEE et al. 2012). The allelic diversity revealed by SSR primers was sufficient to distinguish between the cultivars and landraces. The allelic variation was lower within the cultivar group than among landraces, indicating the possibility to exploit distant relatives to broaden the genetic basis of durum wheat and improve the quality of semolina/pasta and couscous coming from these cultivars. In North Africa and especially in Tunisia, 'karim' is one of the most cultivated varieties but was recorded as poor quality (Table 3). Thus, to improve our pasta quality, farmers should use new cultivars combining high yield levels with good technological qualities of semolina. To provide better dough quality and gluten strength, breeders should choose good parents such as 'Saragolla', 'Iride', and 'Nasr'. To improve grain protein content, parents should be selected from landraces similar to 'Biskri' and 'Chili'. Moreover, breeders can use 'Grécale' and 'Om Rabii' as parents to enhance the yellow colour index (Table 3 ). Wheat quality breeding programs can be achieved by selecting parental genotypes before inter-crossing on the basis of their genetic distances estimated by variations via molecular markers. Inter-crossing genetically distant genotypes maximizes genetic variation present in breeding populations, which is essential for genetic improvement programs for multigenic characters such as semolina quality in durum wheat. As a breeding approach and strategy, we can refer firstly, to Tables 1 and 3 to select parents genotypes on the basis of pedigrees and technological quality parameters. Secondly, we have an idea about the genetic distance between varieties. And finally, we can use moreover than $G l i-\gamma-45 / G l i$ $\gamma-42$ and glutenin alleles, some SSR marker (Table 4) like an indicators for a rapid quality analysis of the first generations of cultivar lines.

\section{ACKNOWLEDGEMENT}

This work was supported by the Ministry of Higher Education and Scientific Research of Tunisia and the Ministerio de Economía y Competitividad in Spain under Grant number AGL 2012-38345.

RESUMO: Nosso estudo enfoca a análise molecular da diversidade genética em 15 variedades de trigo duro tunisiano e a avaliação da eficiência de alguns marcadores disponíveis para selecionar genótipos valiosos para propriedades tecnológicas de semolina (ou seja, parâmetros relacionados à sedimentação sds, tempo de mistura e resistência à degradação do mixógrafo, teor de proteína dos grãos e cor amarela). Enquanto vários marcadores foram validados, outros não foram informativos dentro dos genótipos utilizados. Foi detectado um alto nível de conteúdo de informação polimórfica (pic), com uma média de 5,2 alelos polimórficos por locus e 0,6 média. Variedades antigas têm alto teor de proteína no entanto; variedades modernas exibem forte força de glúten. Nossos resultados abrem, assim, a oportunidade de escolher pais valiosos com base em pedigrees, propriedades tecnológicas e distâncias genéticas; e nos levam a selecionar marcadores eficientes para a estratégia de seleção da estratégia regional de terras indígenas (rils).

PALAVRAS-CHAVE: Trigo duro. Diversidade genética. Sedimentação SDS. Mixógrafo. Teor de proteína. Índice amarelo. 


\section{REFERENCES}

ANDERSON, J. A.; CHURCHILL, G. A.; AUTRIQUE, J. E.; TANKSLEY, S. D.; SORRELLS, M. E. Optimizing parental selection for genetic linkage maps. Genome, n. 36, p. 181-186, 1992. https://doi.org/10.1139/g93-024

BABAY, E.; HANANA, M.; MZID, R.; SLIM-AMARA, H.; CARRILLO, J. M.; RODRÍGUEZ-QUIJANO. M. Influence of allelic prolamin variation and localities on durum wheat quality. Journal of Cereal Science, $n$. 63, p. 27-34. 2015. https://doi.org/10.1016/j.jcs.2015.01.008

BREVIS, J. C.; MORRIS, C. F.; MANTHEY, F.; DUBCOVSKY, J. Effect of the grain protein content locus $G p c-B 1$ on bread and pasta quality. Journal of Cereal Science, n. 51, p. 357-365, 2010.

https://doi.org/10.1016/j.jcs.2010.02.004

BRITES, C.; CARRILLO, J. M. Influence of high molecular weight (HMW) and low molecular weight (LMW) glutenin subunits controlled by Glu-1 and Glu-3 loci on durum wheat quality. Cereal Chemistry, n. 78, p. 5963. 2001. https://doi.org/10.1094/cchem.2001.78.1.59

CARRILLO, J. M.; VAZQUEZ, J. F.; RUIZ, M.; ALBUQUERQUE, M. M. Relationships between gluten strength and gluten components in Spanish durum wheat landraces, in: Bushuk, W.; Tkachuk, R. (Eds.). Gluten Proteins. AACC, (St Paul, MN), 1991. p. 268-277.

CARRERA, A.; ECHENIQUE, V.; ZHANG, W.; HELGUERA, M.; MANTHEY, F.; SCHRAGER, A.; PICCA, A.; CERVIGNI, G.; DUBCOVSKY, J. A deletion at the Lpx-B1 locus is associated with low lipoxygenase activity and improved pasta color in durum wheat "Triticum turgidum ssp. Durum". Journal of Cereal Science, n. 45, p. 67-77, 2007. https://doi.org/10.1016/j.jcs.2006.07.001

CLARKE, F. R., CLARKE, J. M., MC CAIG, T. N., KNOX, R. E.; De PAUW, R. M. Inheritance of yellow pigment concentration in seven durum wheat crosses." Canadian Journal of Plant Science, n. 86, p. 133-141, 2006. https://doi.org/10.4141/p05-083

D'EGIDIO, M. G.; MARIANI, B. M.; NARDI, P.; NOVARO, P.; CUBADDA, R. Chemical and technological variables and their relationships: a predictive equation for pasta cooking quality. Cereal Chemistry, n. 67, p. 275-281, 1990.

DICK, J. W.; QUICK, J.S. A modified screening test for rapid estimation of gluten strength in early generation durum wheat breeding lines. Cereal Chemistry, n. 60, p. 315-318, 1983.

https://doi.org/10.1002/star.19880401014

DICK, J. W.; YOUNGS, V. L. Evaluation of durum wheat, semolina and pasta in the United States. In: FABRIANI, G.; LINTAS, C. (Eds.). Durum: Chemistry and Technology. American Association of Cereal Chemists, (St. Paul, MN) 1988, p. 237-248.

EDWARDS, N. M.; GIANIBELLI, M. C.; MCCAIG, T. N.; CLARKE, J. M.; AMES, N. P.; LARROQUE, O. R.; DEXTER, J. E. Relationships between dough strength, polymeric protein quantity and composition for diverse durum wheat genotypes. Journal of Cereal Science, n. 45, p. 140-149, 2007. https://doi.org/10.1016/j.jcs.2006.07.012

ELIAS, M. E.; MANTHEY, F. A. End products: Present and future uses: Durum Wheat breeding current approaches and future strategies. Crop Science, n. 1, p. 63-85, 2005.

FINNEY, K. F.; SHOGREN, M. D. A ten-gram mixograph for determining and predicting functional properties of wheat flours. Bakers Digest, n. 46, p 32-47, 1972. 
GUPTA, R.; BEG Q. K.; LORENZ, P. Genetic mapping of 66 new microsatellite (SSR) loci in bread wheat. Theoretical and Applied Genetics. n. 105, p. 413-422, 2002. Doi: 10.1007/s00122-002-0865-9

HENTSCHEL. V.; KRANL, K.; HOLLMANN, J.; LINDHAUER, M.G.; BOHM, V.; BITSCH, R. Spectrophotometric determination of yellow pigment content and evaluation of carotenoids by highperformance liquid chromatography in durum wheat grain. Journal of Agricultural and Food Chemistry 50: 6663-6668. 2002. https://doi.org/10.1021/jf025701p

JOPPA, L. R.; CANTRELL, R. G. Chromosomal location of genes for grain protein content of wild tetraploid wheat. Crop Science, n. 30, p. 1059-1064, 1990.

https://doi.org/10.2135/cropsci1990.0011183x003000050021x

KHAN, I. A., PROCUNIER, J. D., HUMPHREYS, D. G., TRANQUILLI, G., SCHLATTER, A. R., MARCUCCI-POLTRI, S. ; FROHBERG, R. J. DUBCOVSKY. Development of PCR-based markers for a high grain protein content gene from Triticum turgidum ssp. Dicoccoides transferred to bread wheat. Crop Science, n. 40, p. 518-524, 2000. https://doi.org/10.2135/cropsci2000.402518x

KNOX, R. E.; HOUSHMAND, S.; CLARKE, F. R.; CLARKE, J. M.; AMES, N. A. In: The gluten Proteins: 8th Gluten workshop, LAFIANDRA, D., MASCI, S.; R. D'OVIDIO (Ed.). The royal society of chemistry, Vieterbo (Italy), 2004. p. 148-151.

KOVACS, M. I. P.; HOWES, N. K.; LEISLE, D.; ZAWISTOWSKI, J. Effect of two different low-molecularweight subunits on durum wheat pasta quality parameters. Cereal Chemistry, n. 72, p. 85-87, 1995.

Langner M., Krystkowiak, K; Salmanowicz, B. P; Adamski, T; Krajewski, P; Kaczmarek, Z; Surma, M. The influence of Glu-1 and Glu-3 loci on dough rheology and bread-making properties in wheat (Triticum aestivum L.) doubled haploid line. Journal of the Science of Food and Agriculture. n. 97, p. 5083-5091, 2017. https://doi.org/10.1002/jsfa.8385

LAW, C. N.; BHANDARI, D. G.; SALMON, S. E.; GREENWELL, P. W.; FOOT, I. M.; CAUVAIN, S. P.; SAYERS E. J.; WORLAND. A. J. Novel genes on chromosome 3A influencing bread making quality in wheat, including a new gene for loaf volume, Lvll. Journal of Cereal Science, n. 41, p. 317-326,

2005. https://doi.org/10.1016/j.jcs.2004.11.003

MARTINEZ, M. C.; RUIZ, M.; CARRILLO. J. M. New B low Mr glutenin subunit alleles at the Glu-A3, GluB2 and Glu-B3 loci and their relationship with gluten strength in durum wheat. Journal of Cereal Science, $\mathrm{n}$. 40, p. 101-107, 2004. https://doi.org/10.1016/j.jcs.2004.04.010

MARTINEZ, M. C.; RUIZ, M.; CARRILLO, J. M. Effect of different prolamin alleles on durum wheat quality properties. Journal of Cereal Science, n. 41, p. 123-131, 2005. https://doi.org/10.1016/j.jcs.2004.10.005

MESFIN, A.; FROHBERG, R. C.; ANDERSON, J. A. RFLP markers associated with high grain protein from Triticum turgidum L. var. dicoccoides introgressed into hard red spring wheat. Crop Science, n. 39, p. 508-513, 1999. https://doi.org/10.2135/cropsci1999.0011183x003900020035x

NAZCO, R.; VILLEGAS, D.; AMMAR, K.; PENA, R. J.; MORAGUES, M.; ROYO, C. Can Mediterranean durum wheat landraces contribute to improved grain quality attributes in modern cultivars? Euphytica, n. 185, p. 1-17, 2012. https://doi.org/10.1007/s10681-011-0588-6

PANTHEE, D. R.; MAJID, R. F. A reexamination of molecular markers for use in marker-assisted breeding in tomato. Euphytica, n. 184, p. 165-179, 2012. https://doi.org/10.1007/s10681-011-0544-5 
PATIL, R. M.; OAK, M. D.; TAMHANKAR, S. A.; RAO, V. S. Molecular mapping of QTLs for gluten strength as measured by sedimentation volume and mixograph in durum wheat (Triticumturgidum $\mathrm{L}$. sspdurum). Journal of Cereal Science, v. 49, n. 3, p. 378-386, 2009. https://doi.org/10.1016/j.jcs.2009.01.001

PATIL, R. M.; OAK, M. D.; TAMHANKAR, S.A.; RAO, V.S. Identification of gluten protein subunits and their PCR amplified products related to sedimentation volume in durum wheat. Journal of Plant Biochemistry and Biotechnology, n. 15, p. 47-50, 2006. https://doi.org/10.1007/bf03321901

ROHLF, F. J. 1998. NTSYS-pc: numerical taxonomy and multivariate analysis system Version 2.0. Applied Biostatistic.

RONCALLO, P. F.; CERVIGNI, G.; JENSEN, C.; MIRANDA, R.; CARRERA, A.; Helguera, M.; Echenique, V. QTL analysis of main and epistatic effects for flour color traits in durum wheat. Euphytica, n. 185, p. 77-92, 2012. https://doi.org/10.1007/s10681-012-0628-x

RUIZ, M.; CARRILLO, J. M. Separate effects on gluten strength of Gli-1 and Glu-3 prolamin genes on chromosomes 1A and 1B in durum wheat. Journal of Cereal Science, n. 21, p. 137-144, 1995. https://doi.org/10.1016/0733-5210(95)90029-2

SISSON, M. Role of durum wheat composition on the quality of pasta and bread. Food Global Science Books, n. 2, p. 75-90, 2008.

SOKAL, R. R.; Michener, C. D. A statistical method for evaluating systematic relationships. The University of Kansas science bulletin, n. 38, p. 1409-1438, 1958.

SOMERS, D. J.; ISAAC, P.; EDWARDS, K. A high-density microsatellite consensus map for bread wheat (Triticum aestivum L.). Theoretical and Applied Genetics, n. 109, p. 1105-1114, 2004. https://doi.org/10.1007/s00122-004-1740-7

SUNDARAM, G. R.; VENKATESAN, T.; KUNNUMMAL, K. V. Genetic diversity among cultivars, landraces and wild relatives of rice as revealed by microsatellite markers. Journal of Applied Genetics, n. 48, p. 337-345, 2007. https://doi.org/10.1007/bf03195230

VAZQUEZ, J. F.; RUIZ, M.; NIETO-TALADRIZ, M.; ALBUQUERQUE, M. M. Effects on gluten strength of low Mr glutenin subunits coded by alleles at the Glu-A3 and Glu-B3 loci in durum wheat. Journal of Cereal Science, n. 24, p. 125-130, 1996. https://doi.org/10.1016/j.jcs.2004.04.010

ZHANG, W.; CHAO, S.; MANTHEY, F.; CHICAIZA, O.; BREVIS J. C.; ECHENIQUE, V.; DUBCOVSKY. J. QTL analysis of pasta quality using a composite microsatellite and SNP map of durum wheat. Theoretical and Applied Genetics, n. 117, p. 1361-1377, 2008. https://doi.org/10.1007/s00122-008-0869-1 